\title{
ASSESSING THE IMPACT OF AREA-BASED INITIATIVES IN DEPRIVED NEIGHBORHOODS: THE EXAMPLE OF S. JOÃO DE DEUS IN PORTO, PORTUGAL
}

Increasing interest in the dialectical relationship between space and social practice has brought new theoretical perspectives not only to the study of society (Lobao et al., 2007), but also to the study of poverty and social exclusion. While on the one hand authors have emphasized the role of social and institutional structures and actions shaping space, on the other they have examined how neighborhood conditions (in terms of image, stability, location, and connections with the wider city) affect social relations.

Besides economic and distributional issues relating to high levels of social and economic inequality between social groups (Alves, 2015), or family and individual circumstances (Dekker \& van Kempen, 2008), it has been noted how the symbolic, social, and physical geography of where people live, in terms of social composition, housing tenure, and built environment, have shaped opportunities (Alves, 2010; Turok et al., 1999). On this issue, Soja (2009) argues that: "taking the socio-spatial dialectic seriously means that we recognize that the geographies in which we live can have negative as well as positive consequences on practically everything we do" (idem: 2). The greater emphasis upon space and geography has generated new interest in the urban spatial structure and its contents and in the processes involved in the production and reproduction of inequality (Soja, 2009; Gotham, 2003).

In this debate it has been recognized that discourses, that is, statements that incorporate judgements, ideologies, and ideas (Spicker, 2007; Foucault, 1987) reinforce, consciously or unconsciously, the negative representation or stigmatization of areas and groups (Power, et al., 2005; Alves, 2012; Wacquant et al. 2014). On this issue, Hancock and Mooney (2013) point out that the ghetto discourse that has reinforced processes of social and spatial marginalization is precisely part of the problem of marginalization of these areas and their occupants. This type of narrative, which distinguishes problematic places and people from supposedly 'normal' instances, produces and 
reproduces stigmatization rather than questioning the logic and failure of the social systems that have generated inequality in cities.

These discourses have also put pressure upon governments to act locally. As a consequence, on various scales of intervention, governments of very different political complexions (Power at al., 2005: 113) have used area-based initiatives (ABIs) to address problems of urban disadvantage.

Rae (2011) identifies three main reasons that explain the preference of policy-makers and activists for the targeting of extra resources on geographical areas which are seen as experiencing the severest disadvantages. First, because "direct targeted action" is a clear indication that governments are doing something about 'problem' areas and the people in them. Second, because this approach channels funds toward areas rather than individuals. And, finally, because the area-based approach reaffirms the pathological nature of neighborhood deprivation, whereby their internal characteristics are seen as the cause of the problem rather than a symptom of wider structural factors (Rae, 2011: $335)$.

Whilst at the political level ABIs have been seen as a solution to socio-economic deprivation and urban decay, and a mode through which to improve local urban governance, at the academic level they have raised several epistemological concerns related to their goals, ideological assumptions, and social effects. Two opposed positions find expression in this debate. On the one hand, there are critical theorists who claim that the structural inequalities expressed spatially cannot be resolved through ABIs. For example, Pugalis (2013), who designates area-based interventions as a "curative form of urbanism" (idem: 619), argues that these regeneration initiatives may be hitting their targets but they are often missing the point of improving social, economic, and environmental conditions (Pugalis, 2013: 618). On the other hand, there are those who consider that ABIs focused upon deprived neighbourhoods have, in many cases, improved the quality of these areas as regards housing and the built environment, and have also promoted community development, social planning, local capacity development, and social capital (Andersen et al., 2013; Tyler et al., 2013). 
However, these authors also recognize that, despite the existence of more sophisticated knowledge concerning the nature of policy problems and the shortcomings of previous approaches, changes in practice have been limited (Rae, 2011: 340), owing to a focus upon physical results and time constraints (Bolt \& van Kempen, 2010; Goetz, 2011).

This paper contributes to existing literature on the evaluation of ABIs in deprived neighborhoods in a number of ways. First, it helps to fill an analytical gap regarding the criteria for evaluating ABIs both from a processual and a substantive perspective vis-à-vis their effects on families and neighborhoods. Second, by using the case study research as an evaluation method (Yin, 2014), it discusses the relationship between political ideologies and political strategy formulation and implementation and their effects on social and territorial stigmatization.

The case study presented in this paper is a useful means to discuss these issues for several reasons. First, because it concerns a large and deprived suburban housing estate that over time has become an object of political dispute and of a territorial stigmatization that has negatively affected its residents. Second, because it involves an ABI that, on the one hand, was co-funded by an initiative launched by the European Commission to promote 'inter-sectoral coordination', 'partnership', and 'participation', and, on the other hand, following a change in municipal power in 2001 , and several subsequent strategy shifts, the decision to demolish 25 blocks of social housing involving the displacement of around 1,600 residents, some to already problematic social housing estates. The paper, therefore, focuses upon the evaluation of area -based initiatives and this topic is analysed from a theoretical and empirical point of view.

The remainder of the paper is structured as follows. The next section presents a literature review around the topic of evaluation, in which the various traditions, purposes, and evaluation methods are briefly discussed. The empirical element of the paper is structured around several interconnected sections. It begins with a description of the strategies formulated over time in the S. João de Deus (SJD) neighborhood, especially under the URBAN II initiative, in which the SJD was nominated as 
a priority area of intervention. In this regard, the main guidelines and principles of the funding program are presented in order to ascertain whether or not local regeneration practices were consistent with these general principles. I then present a comprehensive evaluation framework formulated to scrutinize how far the initiative transformed institutional practices of governance and contributed to trajectories of socio-economic integration. I then critically confront discrepancies between my analytical results and those presented by official ex-post evaluations. On this issue, I question the uncritical approach undertaken by an independent consultant on behalf of the European Commission (ECOTEC, 2010a; 2010b), arguing that it overlooks the 'uncomfortable' drawbacks of the intervention (Flyvbjerg, 2013).

\section{Theories and practices of evaluation}

In reflecting upon the various goals or uses of ex-ante, on-going, and ex-post evaluation, Ferrão (1996) identifies three main types: i) the instrumental, in which assessment is seen as an instrument for improving the implementation and management of programs; ii) the strategic, in which the review is seen as an instrument to promote dialogue, exchange ideas, and collective learning, and iii) the substantive, in which it is expected that evaluation generates feedback that will help to inform future rounds of policy-making. This idea of evaluation as "a source of policy learning, institutional innovation and citizenship" (Ferrão \& Mourato, 2010: 141), that should stimulate broader exercises of strategic and substantive utility (Ferrão, 1996), is relatively new.

While traditional evaluation models and methods have been criticized owing to their tendency to ignore what is not measured mathematically and to overestimate what is measured quantitatively (Hambleton \& Thomas 1995: 12), this new approach claims that evaluation should not be restricted to a set of technical and bureaucratic procedures but should be an interactive and open process (Stame, 2004: 59).

These and other criticisms, including those related to the fact that evaluation does not occur in an ideology-free social vacuum but in contexts where political, economic, and social forces affect 
evaluation results, has opened the way to a paradigmatic shift in the field of evaluation. The positivist and technocratic paradigm has been partially replaced by post-positivist approaches that claim that reality is a social construct mediated by socially and historically constituted practices and specific theoretical and ideological frameworks (European Commission, 2013: 19).

Considering that the activity of evaluation is a normative, rather than an ideologically neutral or apolitical, activity, several authors (Healey, 1997; Guerra, 2002) have advocated greater use of more democratic and pluralistic processes of evaluation so as to acknowledge all persons and groups that have interests in, and are potentially affected by, the system being evaluated, or by the evaluation itself (Klecun \& Cornford, 2005: 236). Furthermore, recognizing the enormous variety of competing interests, rationalities, and ideologies that make up the social system, researchers have advocated the use of the case study and of concrete and practical knowledge:

'sometimes we simply have to keep our eyes open and look carefully at individual cases - not in the hope of proving anything, but rather in the hope of learning something!' Hans Eysenck quoted by Flyvbjerg (2006:7).

As Andersen et al. (2013) emphasize, according to social constructivism, knowledge is produced and distributed in multiple ways so it is not possible to claim that certain forms of knowledge are more important or correct than others (Andersen et al., 2013: 104). These authors also claim that knowledge is context-dependent, that it cannot be separated from either the context in which it is developed or the purposes of its use.

The evaluation of ABIs corroborates these findings, that is, knowledge of what works and why it has to be understood in the context of its social relations. The findings also have to be evaluated using a critical approach, for although ABIs claim to be 'community-led' or 'for the community', they may often disregard community interests (Pugalis, 2013: 620). Also, it has been found that many of the goals proclaimed by policy-makers have never been implemented. On this issue, Lawless (2012) has shown the inadequate community engagement of initiatives in the UK, while 
for Aalbers and van Beckhoven (2010) "integration is often a term used by policy-makers but not implemented", owing to the division of funds between and within different policy fields (Aalbers \& van Beckhoven, 2010: 449).

Even in countries with a longer tradition of development and evaluation of these initiatives, there is a lack of consensus regarding many issues such as the optimal scale to implement these initiatives. In this regard, some authors have claimed the benefits of wider spatial scales to avoid neighbourhood stigmatization and to minimize the scalar mismatch between problems and their solutions. Other commentators have, rather, argued that wider scales lead to a dispersion of investment and do not favor the promotion of community identities and the enhancement of public services (Kearns \& Parkinson, 2001). Rhodes et al. (2005) claim that it was not possible to correlate in a systematic way the success of initiatives undertaken in urban regeneration programs with the size of the target areas, the duration of the initiative, or the predominant thematic approach. However, they do identify organizational and procedural factors that can affect the success of these initiatives. Also, Engberg and Larsen (2010) emphasize the importance of these factors, claiming that there are two main types of interaction that are crucial for the success of ABIs. One is interaction between local government and planners involved in urban area-based regeneration projects, including local public employees and project managers, personnel from voluntary organizations and other civil associations. The other is within the local government organization itself, that is, the interaction between its several specialized administrative sections regarding their ability to communicate and collaborate (Engberg \& Larsen, 2010:552).

Besides structural factors such as the welfare regime and the housing systems that explain various state commitments regarding issues of equality and redistribution (Alves \& Andersen, 2015), contextual conditions such as the availability of instruments for democracy, accountability, and citizen participation in governance networks, are considered crucial to explain more or less 
comprehensive and community-led approaches in urban regeneration (Parés \& Martí-Costa, 2011; Dekker \& Van Kempen, 2008).

Considering, on the one hand, this theoretical background and given that the general principles underlying urban regeneration initiatives are 'inter-sectoral coordination', 'partnership', and 'participation', and on the other, the gap in the literature relating to how ABIs are accessed or how to evaluate the impact of these initiatives upon modes of local governance and social change, this paper develops an analytical framework structured around ideas that intersect the concepts of 'governance', 'institutional capital', and 'social inclusion'. Whist the case study research methodology is presented in the empirical part of this paper, here it is worth discussing some basic theoretical propositions that arise from the concepts used in this analytical framework.

The heuristic concept of governance involves analytical and normative notions related to transformations that have taken place in state models of organization and action both in terms of formal structures of government and institutional relations with other sectors of society, including communities and the private sector (Healey et al., 2002). This research focuses upon the effects of practical processes of strategy formulation and implementation on practices and work routines and levels of participation and interaction between actors and institutions.

The concept of institutional capital is linked to three elements of social interaction. The first is the flow of knowledge of various kinds between stakeholders in a locality. The second are the relational networks introduced into the governance process by the stakeholders in which resources of trust and co-operation contained in such networks are crucial. The third element is the ability of stakeholders and their networks to draw resources, rules, and ideas into the task of collective action. This is the capacity of stakeholders to mobilize knowledge and relational resources to act collectively for some common goal (Cars et al., 2002).

Considering that actions in the domains of training, education, job-creation, housing, ..., undertaken in urban regeneration initiatives can affect opportunities for social integration, the aim, under the 
general concept of social inclusion, was to assess the way they impacted on opportunities of socioeconomic integration in the spheres of market exchange, redistribution, and reciprocity (Murie \& Musterd, 2004).

The next section presents the empirical results of the paper, being structured in several complementary parts. The first part describes the various phases of construction, occupation, and densification of the SJD neighbourhood and the reasons for its physical and social degradation. The second part discusses the purposes and goals of the two main ABIs that targeted the neighbourhood, that is, the National Program against Poverty (1990/94 e 1995/99) and the URBAN II Initiative (2000/2006), and the reasons that led to a large- scale demolition of 25 buildings and the displacement of residents to other social housing estates. The third part presents the analytical framework used in the evaluation of this initiative. Here are discussed issues of social and territorial stigmatization and the effects of forced displacement. The fourth part compares the results of this research evaluation with those presented by official reports on the same initiative, arguing that the latter were used by politicians, state bureaucrats, and their networks as a means of legitimizing their policies and their symbolic power (Wacquant: 2014).

\section{Empirical element: SJD local context and trajectory of decline}

SJD is a peripheral neighbourhood (see Figure 1) which, like other social housing estates built on the outskirts of Porto, "was born poor" (Alves, 2010: 180) in terms of urban planning, social occupation, and location. The neighbourhood was constructed in a marginal area, with an incipient urbanization process and very low or non-existent economic and social opportunities (such as jobs, social and private services etc.).

Figure 1 about here.

In recent decades the context of de-industrialization in Porto has mainly affected the eastern part of the city, namely the district of Campanhã where the SJD is located (Alves, 2015). In 2000 the 
population of the SJD was officially estimated to be 2,600 inhabitants. About 448 families, amounting to a population of around 1,600 inhabitants, were living in 144 single-family houses constructed in 1944 (see Figure 2) and the rest in 28 multi-family housing units built over several decades to respond to the growing demand for housing in the city.

Figure 2 about here.

In this regard, it is worth noting that, following Portugal's granting independence to its colonies in the mid 1970s, hundreds of thousands of people from Mozambique, Angola etc. arrived in Portugal. In a context of lack of public control over land development and an absence of housing, these 'retornados' (returnees), as well as low-income families arriving from rural districts, were forced to seek accommodation in the informal market, that is, housing constructed without reference to planning rules, planning permission, or minimum standards. This occurred in an SJD which saw the expansion of a shanty town inhabited by Roma, African, and ex-rural dwellers with high levels of social and economic need.

Recognition of this situation led in the 1990s to the development of a project funded by the National Program against Poverty (Programa Nacional de Luta contra a Pobreza), which was inspired by the European Program III to Combat Poverty (1989-1994) and funded by national and local bodies. This project was coordinated by an institution linked to the Catholic Church, which was already working in the neighbourhood to support children, youth, and families. Actions developed under this project enabled the eradication of illegal houses and the construction of 12 new blocks of multifamily housing - in total 270 dwellings - (see Figure 3), as well as the construction of equipment and services for youth, the elderly, and the unemployed.

Figure 3 about here. 
Nevertheless, by the end of the program disagreements over the way resettlement occurred and who should manage the new multi-family housing led to institutional conflict between the project leader (nominated by the national and local governments) and the local government itself.

As a consequence of these disagreements, the municipality did not accept the transfer of the new blocks to the municipal housing stock. When the project ended, no institution was responsible for the new housing blocks. The tenants were not paying rent and in some cases they were exchanging/selling houses according to their preferences or needs (for example, attempting to match housing size to family size). As a consequence, over time institutional abandonment became rife, the neighborhood became increasingly difficult to manage, and a process of urban decay set in (Alves, 2010).

Hence the SJD came to be seen as a "hard psychotropic territory" and one of advanced marginality (Fernandes, 1998; Uitermark, 2013), less in the sense that it represented a daily burden to its immediate actors (the elderly, women and children), but in the sense of being seen as a dangerous and degrading space (Hancock \& Mooney, 2013: 52).

The complex problems affecting the SJD neighborhood have justified its selection as a priority area of intervention under the URBAN II, a program launched by the European Commission in the period 2000-2006 to promote the economic and social regeneration of neighborhoods in crisis (European Commission, 2003). The programming document (DGDR, 2001) cites a number of reasons to justify the relevance of the neighborhood as a priority area of intervention: i) a young and ethnically diverse population, that is, $47 \%$ of the total population was less than 24 years old, $34 \%$ of the total were Roma (or Gypsies), and 7\% African; ii) higher than average unemployment rates equivalent to $35.3 \%$ of the total active population; iii) low levels of literacy and educational attainment, and higher levels of state social benefits (such as the minimum income), and iv) higher 
levels of physical degradation (public spaces and buildings), and disorder related to the high concentration and visibility of drug-related problems (traffic and consumption).

Selection of this area took into account socio-economic and housing data, but the choice was mainly political. Two projects were chosen in the metropolitan area of Lisbon, and one in the metropolitan area of Porto. In Porto the initiative was divided administratively over two municipalities - Porto and Gondomar. The initiative covered an area of around $5.7 \mathrm{~km} 2$ and a population of around 27,370 inhabitants (DGDR, 2001). From 2001 to 2006, the total cost of the programme was $€ 15.2$ million, of which $€ 10.1$ million came from the European Regional Development Fund and $€ 4$ million from the local administration (DGDR, 2001).

At the sub-national level, URBAN II was implemented by the municipalities and managed by the Comissão de Coordenação e Desenvolvimento Regional do Norte (CCDRN), a decentralized government body responsible for the regional development of financial instruments, including European Union (EU) funds. It is worth noticing that Portugal is a centralized unitary state (Michalski, 2012) in which the regional level exists but only for administrative reasons, and it remains subordinate to the central state. In the context of the URBAN II, as the managing authority, the CCDRN was in charge of project appraisal, funding allocation, monitoring systems, and project support (ECOTEC, 2010b). It was supported by a technical support structure and a steering committee chaired by the program manager and representatives of the municipal boards involved. Relevant representatives of local communities were not represented on the steering committee.

\section{Strategy shifts in SJD neighborhood: from re-qualification to demolition}

"It cannot be considered a natural process to demolish houses that were recently built" (Wassenberg, 2011: 376).

This section presents contextual elements that help to understand processes of plan formulation and implementation in the São João de Deus neighbourhood, that is, what was planned for the 
neighborhood and how and why changes came about, focusing upon the final decision to demolish almost the entire neighborhood without further intervention. It is worth emphasizing here that the first strategy change occurred after the political shift within the municipality and the second took place over the same political cycle, being associated with the non-implementation of the plan initially envisaged.

The first strategy was drawn up during the final phase of URBAN I in 2000 by the socialist party that ruled Porto's local government until 2001. It was formulated by the technical team which was in charge of URBAN I in Vale de Campanhã, a disadvantaged area located in the southern part of the district in an adjacent area of SJD. This plan was then formulated by Fundação Porto Social involving community groups, local institutions, and residents' associations. The strategy aimed at improving the conditions of the neighborhood by developing physical measures such as the construction of a structural pathway or the rehabilitation of the most degraded buildings and public spaces, but also by improving the management of the neighborhood through fora and area committees. The strategy included the resolution of problems relating to the legal status of the buildings, and the development of a range of services and facilities for residents.

In December 2001 the election of a new mayor and a right-wing political party in the municipality led to a strategy shift. In this regard, it is worth mentioning that, during the political campaign for the local government, the SJD neighborhood gained political centrality when the conservative party accused the socialist party of letting the SJD turn into a ghetto, a supermarket of drugs, without order or rule (Alves, 2010). Demonstrating preconceived ideas regarding the occupants of the neighborhood, for example, failing to distinguish between those who lived there as opposed to those who went there for illegal purposes, the leader of the conservative party promised that, if elected, he would regain control of the area. Political narratives about the neighborhood never considered its positive aspects, such as the presence of networks of reciprocity, or the extraordinary resilience shown by vulnerable people faced with long-term institutional abandonment. Symbolically, on the 
day following the election the new mayor visited the neighborhood, re-affirming the intention of radically transforming it. The need to regain control over the area was emphasized in terms of resolving deviant norms and behaviors.

Some months after the election, a redevelopment project was formulated by a team of public officials composed of architects, which followed top-down methodologies. Amongst other aspects, the project was formulated along the following strategic lines defined by the Executive Council: i) the reduction of the population through large-scale demolition of housing stock to clear the site for future development; ii) the construction of a road to cross and afford access to the area; iii) the construction of 124 semi-detached dwellings to rehouse part of the population (groups affected were not stipulated); iv) the re-qualification of the semi-detached dwellings constructed in the 1940s; v) the transformation of the local school into a private university; vi) a plan for reviving the sports venue, and vii) a plan of social action for the purposes of monitoring, supporting, and referring drug addicts who frequent the neighborhood.

By the end of 2002, the project was presented to the inhabitants and the media. Whilst its goals and objectives were generally acceptable, the planning process was criticized for not having involved those directly affected by the initiative, and on the grounds that the demolition of recently constructed buildings would not solve problems of antisocial behaviour (crime, vandalism, drug addiction). Some raised practical concerns related mainly to demolition and relocation. On the one hand, they warned that demolition would only displace social and economic problems to other neighborhoods. On the other, they were afraid of losing their social networks. At the time, nobody expected that the implementation of the project might generate such large-scale evictions and massive forced relocations to other neighborhoods.

The municipality officers stated that the demolition would be more cost-effective than the renovation and maintenance of the buildings, and this would solve the problem of an urban form 
that was reinforcing the neighbourhood's isolation and favoring crime. The demolition began in 2003 in a context of political and social contestation and pronounced police intervention. By the end of 2005, almost the entire neighbourhood was demolished. In December 2008, the last of the 25 blocks of multifamily housing (a total of 562 housing units) was demolished. The decision to demolish was strongly criticized:

Homes and equipment were built, we had a fabulous playground, we made houses and below the houses facilities for education and employment. A beautiful garden even a football field, all was done, a fabulous sports-gym pavilion for community, everything was abandoned, vandalized, and look, it's a sad story you know? (Local priest and a former leader of the project against poverty developed in the neighborhood).

Wacquant (2007), who has made an important contribution to critical research on contemporary urban marginality (Jensen \& Christensen, 2012), characterizes the SJD as an example of state symbolic demonization to legitimize and justify special measures:

"in the wake of a series of sensationalistic reports on television, the neighbourhood of São João de Deus, a 'slummified' sector of northern Porto with a strong and conspicuous presence of gypsies and Cape Verdean descendants, is nowadays known throughout Portugal as the infernal incarnation of the 'bairro social degradado'. The municipality of Porto took advantage of its squalid reputation as a 'hipermercado das drogas' to launch an 'urban renewal' operation which, thanks to a series of muscular police raids, aims essentially at expelling and scattering the local addicts, squatters, unemployed and other human detritus to insert the neighbourhood back into the city's real estate circuit - without worrying in the slightest way over the fate of the thousands of residents thus displaced." (Wacquant, 2007: 69).

The demolition of the housing blocks was not informed by theories concerning how and why the strategy should work in the neighborhood but was part of a political project of urban cleansing.

Demolition in the SJD led to 162 evictions and the displacement of 430 households to other publicly-funded neighborhoods. According to authorities, evictions occurred when housing units were being used for illicit purposes such as second homes, or where there was illegal occupation. About $45 \%$ of displaced tenants were rehoused in the parish of Campanhã, and many in large 
housing estates. Despite initial promises, neither the construction of new semi-detached dwellings to rehouse part of the population occurred, nor did the promised re-qualification of the 144 singlefamily houses built in the 1940s and currently inhabited by an aged population (see Figure 4).

Figure 4 about here.

There was never an official explanation as to why the other measures were not implemented, and the neighborhood was almost entirely demolished. This was presented by the technical teams as a political decision that did not seek to explore any strategies for consensus. There were no opportunities for participation to influence the way the initiative was designed and implemented either by citizens or non-government institutions and front-line staff. Also, the SJD became a taboo topic in the municipality, the technical teams not wishing to provide further information about the case. Access to information was very restricted.

\section{A case study evaluation of the SJD: Analytical framework and methods}

Here I present the lines of inquiry and methodologies used in this case study which began in 2004, when the programming documents of the URBAN II initiative identified the SJD as a priority area of intervention. The starting point of the research was the reconstruction of the theoretical background of the URBAN initiative and of the program formulated for the SJD neighborhood. Following Rhodes et al. (2005), the aim was to try to learn the explicit and implicit contextmechanism-outcome configurations, paying special attention to how the program was supposed to work and to generate outcomes in the neighborhood.

The aim of both rounds of the URBAN initiative was to contribute to positive improvements in distressed neighborhoods, though measures that would support a better inter-sectoral co-ordination of activities, and involve the community and local stakeholders in decision- making (Swianiewicz et al. 2011; Carpenter, 2006). 
In order to evaluate the impact of this initiative, whether intended or contingent, the evaluation framework built around the mutually reinforcing concepts of governance - institutional capital and social inclusion - was subsequently translated into research questions (see Table 1). These questions were then organized into two different qualitative semi-structured guidelines with the aim of evaluating the experience of the respondents in the process of conception and implementation of initiatives.

Table 1 about here.

One guideline was used to conduct interviews with officials who were directly involved in policymaking, implementation, or management of the interventions. The other guideline was used to conduct interviews with residents and ex-residents of the neighborhood who were directly affected by the initiative.

The selection of interviewees was based upon household composition, age group, and place of residence (in the neighbourhood/ outside the neighbourhood, though displaced by the initiative) in order to include sub-groups of the population that might have different experiences or perceptions of the initiative. The semi-structured interviews were conducted with 20 people, but informal conversations were frequently undertaken in the neighborhood.

The semi-structured interviews, which were digitally recorded with the permission of each interviewee and subsequently transcribed, involved descriptive, normative, and causal questions about what happened, the level of satisfaction of individuals and institutions, the relations of cause/effect between methodologies and outcomes, and impacts upon individuals and neighborhoods.

\section{Empirical key findings}


The qualitative information collected during interviews revealed the prevalence of weak forms of institutional collaboration and a decision-making process characterized by top-down approaches, without the participation of local actors. Residents and local institutions had no opportunity to influence decision-making processes and the initiative was managed through specialized and compartmentalized governmental agencies. Major decisions taken by the municipal authority were subsequently implemented by two governmental agencies. The Domus Social, which in Porto is responsible for the provision and management of the housing stock, was appointed to undertake the implementation of physical measures, while the Fundação Social do Porto caters to matters of social and economic intervention. The idea of interdepartmental co-operation, which was central to the European initiative, was passed over at the local level. The political decision that agencies should keep their traditional 'silo' approach, concerning their traditional competencies and follow their own procedures and internal issues, blocked any effort to achieve horizontal co-ordination. The following two excerpts illustrate that the resettlement process did not involve technical supervision and monitoring methodologies or interdepartmental coordination:

The information came to the school through the media. We were not informed about the restructuring plan for the neighborhood. We were seeing the blocks that were to be demolished, and people were saying that the school would close. And this rumor has spread and many parents do not enroll their children in this school. (Teacher at the primary school of SJD - Escola Básica $1^{\circ}$ Ciclo S. João de Deus which is still open today).

There was no concern with anticipating impacts of decisions, minimizing damage, particularly for children who were transferred abruptly [...]. We asked that the demolitions were not made in the middle of the year because it would mean changes in school and a number of modifications that could possibly harm children. (Social Assistant in a local association).

Table 2 shows the program elements that were actually delivered in the SJD neighborhood according to the main strategic lines and goals defined for the URBAN II initiative in Porto/Gondomar. The results are critically analyzed within the framework of the qualitative evaluation previously presented. 
Table 2 about here.

The first priority - "Regenerating the urban character of the area" - occurred through a project of demolition and cleansing of the neighborhood. Around $85 \%$ of the buildings in the neighborhood were demolished. Constructed in the 1940s, the older houses were not renovated as promised, and as soon as their occupants died or were transferred to other areas these houses were progressively sealed. Currently, only a third of the houses are occupied while dozens are sealed off. The residents considered that the neighborhood had improved in terms of tranquility, but became an empty, abandoned, and gloomy place.

The effects of displacement and relocation were not the same for all sub-groups of the population. Two significantly divergent positions were identified in interviews. On the one hand, a group reporting high levels of satisfaction regarding the new housing conditions (in terms of housing quality and dimension, and the state of the neighborhood) described the houses as more clean, safe, and giving rise to less crime and conflict. On the other hand, tenants who were discontented with the decision to demolish and rehouse claimed that the process was stressful and stigmatizing. Tenants felt they lacked agency in the decision to move, and limited opportunity to negotiate with the housing authority, had little information and experienced a decline in their social networks. Some inhabitants felt that they missed the comforts of adequate housing and immediate environment in the new neighborhoods. Their housing conditions worsened in terms of size, quality, and infrastructure (such as public spaces). The relocation of older people was also described as problematic. The older population, which had lived longest in SJD before relocating, described feelings of rootlessness and social isolation in the new areas. They described depressive symptoms regarding their situation in the new neighborhood even whilst acknowledging improvements in housing conditions.

Many of the people were born here and when they had to leave the neighborhood and those they knew they almost died because they had lived many years there. (Former SJD resident). 
I lived in 'H Block of the Damned'. It was said that a person who behaved badly in the other housing estates would be transferred to that block. I lived there and did not think it was an area of problems. It was better than in this new neighborhood where I live now. There, if I was sick two days, everyone would ask for me, about how I was, trying to help. Here in this neighborhood, a person can die and nobody wants to know. Here there are no relations between people like there was there. I'll never find a neighborhood like that, with people always willing to help and with family spirit. (Former SJD resident).

There were people who when they left the neighborhood lasted only one or two months, no more. They felt the lack of gatherings; they felt that they were not well accepted in the new neighborhoods [...]. This destroyed many families, who felt the lack of interaction, and stigmatization in the new neighborhoods. (Former SJD resident).

Resettlement processes did not favor trust between individuals and institutions and problems relating to the breakdown of social networks and support systems were responsible for stigmatization in the new areas.

My aunt faced some problems with her small kid in the new neighborhood, since the other mothers did not let their children play with him, afterwards he did not want to go to school anymore and not even to the street, he was listening to people saying that SJD inhabitants were not welcomed, because they just want to create problems. (Student and SJD resident).

Representatives of local organizations expressed their indignation at the way the neighborhood had been demolished and families were forced to re-house. They claimed that the manner in which processes were implemented disrupted pre-existing social relations and created new problems such as isolation of the elderly and an increase in the school dropout rate, namely among the Roma community. They also pointed out that the implementation procedures were not consistent with principles of democratic involvement, empowerment, and participation enshrined in the URBAN II initiative, and they were unresponsive to the social needs and expectations of the local residents and institutions.

Since many relocations did not involve improvements in environmental or social conditions, but rather had unintended mental health impacts, such as stress and depression (Kearns \& Mason, 2015, 
Clark \& Kearns, 2012), and the loss of personal support networks, interviewees claimed that the intervention did not stimulate life-changing improvements, but created traumatic effects, namely for children and the elderly.

Regarding the impact of resettlement on residents' destinations, it is worth recalling that the highest number of families from the SJD, equivalent to 69 households, was rehoused in the 'Cerco' neighborhood, which before the influx of new people had already amounted to around 3,100 inhabitants. This neighborhood, which was nominated as a priority area of intervention under the URBAN I initiative (see Alves, 2008), was greatly affected by the demolition of SJD. Studies by Fernandes and Ramos (2010) on psychotropic territories of Porto show that: "after the demolition of SJD, the drug scene shifted to the eastern part, to the Cerco neighbourhood and around, extending subsequently to uninhabited spaces (factories, viaducts, abandoned houses)" (Fernandes \& Ramos, 2010: 17).

The second priority - "Social Inclusion and economic and professional qualification" - which involved key objectives such as fighting drug/alcohol addiction and labor market disadvantages was mainly facilitated through measures of employment and training information, and debates around drug addiction issues. The project leader responsible for these measures was not able to identify beneficiaries of training from the SJD, nor any action related to the valorization of local economic activities and the promotion of entrepreneurship. However, it was emphasized that the URBAN II initiative provided the school with financial support to develop innovative projects related to sports, literature etc., and to a day center to offer recreational and educational services to elderly people such as aquagym, basic gymnastics, and poetry lessons.

\section{The official evaluation}

The evaluation set up by the European Commission develops through a vertical, multilayered architecture (European Commission, 1999) and takes place according to a specific time-frame. 
Depending upon the stage at which it is carried out, the evaluation tends to focus upon different concerns. For example, while the phase of ex-ante evaluation develops a form of prospective analysis, using evaluation questions such as 'To what extent are the program objectives justified with regard to the social needs or problems to be solved?' (Relevance), the ex-post evaluation consists mainly of retrospective evaluation. Several questions are usually posed during the phase of ex-post evaluation, such as those regarding effectiveness. Hence: 'To what extent have the expected objectives been achieved?' and 'Have the instruments used produced the expected effects?' Or utility. Hence: 'Are the expected or unexpected effects globally satisfactory from the point of view of direct or indirect addressees?' (European Commission, 1999).

This part of the paper considers the most relevant issues and conclusions regarding the mid-term and ex-post evaluation of the Initiative Porto/Gondomar. In this regard, the mid-term evaluation was commissioned by the regional authority and carried out by an external consultant (Deloitte, 2003), while the ex-post evaluation was commissioned at the EU level and undertaken several years after the end of the programming period by an independent evaluator (ECOTEC, 2010a) in collaboration with CCDRN.

The mid-term evaluation, which is usually performed towards the middle of the implementation, in the case of Porto/Gondomar was performed during a delay in implementation. Relying mainly upon information derived from the monitoring system, this evaluation reported that political change in the City Council Executive resulted in the re-orientation of some policy interventions, with particular consequences for SJD. Regarding the intervention planned for the neighborhood, the report specifies that the strategy will include a full renovation of the neighborhood by decreasing the population density, the eradication of trafficking and drug use, and connection of the urban network with its surroundings. Regarding the decision to demolish part of the neighborhood, it stated that:

\footnotetext{
"The demolition of some blocks will result in a lower concentration of disadvantaged people in that neighborhood, who will be relocated to other neighborhoods in the city. The resettlement should,
} 
however, be accompanied by action to instill in the population habits of maintenance of dwellings" (Deloitte, 2003: 136, own translation).

The only recommendation made in this report regarding the issue of demolition/relocation focuses upon the need to inculcate habits of housing maintenance. No reference is made to the necessity to anticipate the needs of this population, or the various options regarding how and where to rehouse and whether to rehouse whole communities or to scatter individual households across different estates. However, even in very generic terms, the report recommends better articulation between the program manager and the management, the monitoring and the controlling structure. It also recommends prior consultation with a greater number of social partners during the program's financial re-orientation (Deloitte, 2003).

The purpose of ex-post evaluation is to account for the use of resources, to report on the effectiveness and efficiency of the interventions, and to evaluate the extent to which expected effects were achieved. According to the European Commission, such evaluation should calculate all the benefits, costs, and disadvantages of the initiative. It should judge all the effects of the initiative, whether direct or indirect, positive or negative (European Commission, 1999).

Ex-post evaluation of the URBAN II initiative was commissioned by the European Union (DG Regio) and was carried out by ECOTEC, an independent research and consulting company. The evaluation was based upon an assessment of a desk review of all 70 URBAN II programs in various European cities and was combined with discussions with program managers and detailed case studies for 15 URBAN II programs (ECOTEC, 2010a). The Porto/Gondomar program was one of the 15 case studies selected for 'deeper exploration' (ECOTEC, 2010a:7). In its Final Report, ECOTEC (2010a) praised the Porto/Gondomar initiative as: "the only urban regeneration initiative in the area that was based on broader consensus, empowerment, and an integrative participation model" (ECOTEC, 2010b). 
"The integrated approach adopted in the URBAN II programme Porto/Gondomar can be considered a real achievement. It has brought together key stakeholders to work on employment, social inclusion and physical and environmental regeneration in the area. The programme involved a rather balanced and coherent set of physical and urban regeneration; social integration and educational measures based on local partnership proposals" (ECOTEC, 2010b).

Such statements, which reproduce the rhetoric of political discourse and the narrative of the program manager (CCDRN), who stipulates that the initiative "work with the population and not for the people" (ECOTEC, 2010b), was far from borne out in this study. Such a discrepancy can be explained in two ways. Firstly, as evaluation "can bring gains and losses to individuals, groups and institutions" (Hambleton \& Thomas, 1995: 15), local staff, in the name of institutions, report the best results even when interventions prove ineffective. Secondly, establishing such wide scope among programs and case studies, evaluators sacrificed depth and contact with what actually happened at a grassroots level. Such a wide-ranging approach does not generate enough knowledge about each individual case.

\section{Lessons learned}

Essentially, urban regeneration is about improving the quality of life of people in poor and disadvantaged urban areas (Bunyan, 2014: 7). At European and national levels, several urban regeneration programs have been launched to increase financial support to areas in need, allegedly to improve their inhabitants' prospects. However, at a local level, the implementation of ABIs has not always been used as part of a strategy to combat social exclusion, but in a way that raises many doubts, namely about their impact upon the most vulnerable, marginalized, and excluded groups.

The aim of this paper is precisely to evaluate the impact of an ABI that, in an unforeseen way, placed tremendous strain upon residents, institutions, and local governance. By doing this, the following results emerged concerning the factors and circumstances that influence the effectiveness of such initiatives. 
Firstly, the evidence shows that the mélange of social, economic, physical, and organizational problems in some areas reinforce processes of urban decline that cannot be resolved by a narrow approach via sectoral, hierarchical, and uncoordinated procedures. The value of ABIs lies in their competence to comprehend and promote innovative and flexible ways to resolve problems that are identified locally though collaborative methodologies.

Secondly, the existence of different political beliefs and values regarding the main causes and possible solutions to such problems explains the formulation of different strategies, sometimes contrasting in their objectives and approaches, which have to be understood in the context of wider political ideologies and agendas. Political struggles, rather than political commitments, can result in undesired outcomes such as those witnessed in SJD that most emphatically affected those living and working there. As Rae (2011:345) points out: "political partisanship and ideology are over-arching aspects of the process and are the main reason why short-termism dominates a policy sphere which demands a long-term approach" (idem: 345).

Forty years of an authoritarian regime in Portugal may explain the presence of an 'authoritarian' local political culture that, in many cases, has tended to block interactive and collaborative deliberation around crucial issues such as those that affect distressed urban neighborhoods. By failing to acknowledge that socially excluded groups are excluded specifically because they lack the power and resources to take action or even participate in their local community (Gosling, 2008), by reinforcing departmentalism and disregarding the knowledge and experience of the technical team, political leaders have crucially limited the way in which the initiative was formulated, managed, and delivered. Empirical evidence presented in this paper also demonstrates that political discourses that add pathological explanations about the area and its residents reinforce processes of territorial stigmatization that negatively affect social relations and opportunities. Also, by denying the right of housing to the most marginalized inhabitants, the local government contributes to further marginalization of impoverished families. 
Thirdly, although physical intervention can generate infrastructural improvements, demolition and forced evictions only displace problems between different neighborhoods without affecting their causes. This case study shows that the way demolition and displacement occurred in Porto disrupted pre-existing social relations and created new problems such as isolation of the elderly and an increase in school drop-out rates, namely among the Roma community. This case study corroborates Arthurson's (2004) conclusion that "demolition is not a low-cost solution either in financial or social outcomes" (idem: 267), and does not promote innovative and holistic solutions to social and urban problems.

Fourthly, a more optimistic aspect of this case relates to the legacy and lessons of past interventions for present and future initiatives. In this regard, the interviews and follow-up discussions with members of the technical teams involved in previous rounds of European initiatives (eg. URBAN I) evinced strong criticism of the SJD case, arguing that it represented a major setback in terms of urban regeneration practices in Porto. By arguing that events in São João de Deus were not consistent with the principles of democratic involvement, empowerment, and practices of governance enshrined in the European initiatives, these practitioners corroborated the significant role that the European experimental programs had in Portugal, promoting more humanistic values regarding issues of poverty and social exclusion.

Finally, the research highlights a range of conclusions as regards evaluation. The study has revealed that, on the one hand, the dissemination of information about good practices in local programs must be considered more carefully and in more realistic terms, and on the other, well-founded impartial evaluation, is needed to assess so-called 'best practice'. On this issue, we may conclude that in a society structured by conflicting interests defined along lines of class, race, and politics, in which evaluation is no longer perceived as a neutral issue, practices of assessment should move beyond the traditional concern with measuring effect sizes and degrees of goal-achievement to embrace a 
theory-based approach capable of testing the underlying assumptions and potential results of rival strategies (Sanderson, 2002).

Considering that political powers perennially attempt to secure their best interests (Spicer \& Smith, 2008: 77), we should ensure that evaluation take into account the expectations, interpretations, and judgment criteria of all legitimate stakeholders, including those who have very little power or ability to express themselves. As Andersen et al. (2013) point out, there is no single truth or explanation (idem: 106), which is why evaluators should assume a more interactive and mediating role, bringing together the views of all involved in order to generate holistic understandings of what works and for whom.

\section{References}

Aalbers, M. \& Van Beckhoven, E. (2010). The integrated approach in neighborhood renewal: more than just a philosophy? Tijdschrift voor economische en sociale geografie, 101, 449-461.

Alves, S. (2008). A diferença que a participação faz em iniciativas de regeneração urbana. Sociedade e Território, 41, 8-18.

Alves, S. (2010). O Social, o Espacial e o Político na Pobreza e na Exclusão - Avaliação de iniciativas de regeneração de áreas urbanas 'em risco' na cidade do Porto. $\mathrm{PhD}$ Thesis, Instituto Superior de Ciências Sociais, Lisbon University, Portugal.

Alves, S. (2012). The Patterns of Unemployment and the Geography of Social Housing. World Academy of Science, Engineering and Technology, 71, 759-767.

Alves, S. (2015). Welfare State Changes and Outcomes: the Cases of Portugal and Denmark from a Comparative Perspective. Social Policy \& Administration, 49(1), 1-23.

Alves, S. \& Andersen, H.T. (2015). Social housing in Portugal and Denmark: a comparative perspective". ENHR 2015 Housing and Cities in a time of change: are we focusing on People?, Lisboa, ISCTE, 28 June-1July. 
Andersen, H.T., Dimitrova, E. \& Schmeidler, K. (2013). Urban Knowledge and Large Housing Estates in Europe. In: Andersen HT and Atkinson R (Ed.) Production and Use of Urban Knowledge. (pp.103-132). Netherlands: Springer.

Arthurson, K. (2004). From stigma to demolition: Australian debates about housing and social exclusion. Journal of Housing and the Built Environment, 19(3), 255-270.

Bunyan, P. (2014). Regenerating the City: People, Politics, Power and the Public Sphere. Local Government Studies, 1-17. DOI: 10.1080/03003930.2014.982109.

Carpenter, J. (2006) Addressing Europe's Urban Challenges: Lessons from the EU URBAN Community Initiative. Urban Studies, 43(12), 2145-2162.

Cars, G., Healey, P., Madanipour, A. \& Magalhães, C. (2002). Urban governance, institutional capacity and social milieux. London: Ashgate.

Clark, J. \& Kearns, A. (2012) Housing Improvements, Perceived Housing Quality and Psychosocial Benefits From the Home. Housing Studies, 27(7), 915-939.

Deloitte (2003) Avaliação Intercalar do Programa de Iniciativa Comunitária Urban II de PortoGondomar. Porto: Deloitte.

Dekker, K. \& van Kempen, R. (2008). Places and participation: comparing residential participation in post-WWII neighbourhoods in Northwest, Central and Southern Europe. Journal of Urban Affairs, 30(1), 63-86.

DGDR - Direção Geral do Desenvolvimento Regional (2001) Programa de Iniciativa Comunitária URBAN II 2000-2006 Porto-Gondomar. Lisboa: Ministério do Planeamento.

ECOTEC (2010a) Ex-Post Evaluation of Cohesion Policy programmes 2000-06: The URBAN Community Initiative, Final Report prepared for the European Commission, Available at: http://ec.europa.eu/regional_policy/sources/docgener/evaluation/pdf/expost2006/urbanii/final report.pdf (accessed 6 July 2015). 
ECOTEC (2010b) URBAN II Evaluation Case Study: Porto Gondomar - An isolated success story? Available at:

http://ec.europa.eu/regional_policy/sources/docgener/evaluation/pdf/expost2006/urbanii/case studies/porto gondomar.pdf (accessed 6 July 2015).

Engberg, L.A. \& Larsen, J.N. (2010). Context-Orientated Meta-Governance in Danish Urban Regeneration. Planning Theory \& Practice, 11(4), 549-571.

European Commission (1999) The MEANS Collection. Brussels: European Commission.

European Commission (2003) Partnership with the Cities - The URBAN Community Initiative. Luxembourg: Office for Official Publications of the European Communities.

European Commission (2013) EVALSED: The resource for the evaluation of Socio-Economic Development. Brussels: DG for Regional Policy.

Fernandes, L. (1998). O sítio das drogas. Etnografia das drogas numa periferia urbana. Lisboa: Editorial Notícias.

Fernandes, L. \& Ramos, A. (2010) Exclusão social e violências quotidianas em "bairros degradados": etnografia das drogas numa periferia urbana. Revista Toxicodependências, 16(2), 1527.

Ferrão, J. (1996) A avaliação comunitária de programas regionais: aspetos de uma experiência recente. Sociologia-Problemas e Práticas, 22, 29-41.

Ferrão, J. \& Mourato, J. (2010). A avaliação de políticas públicas como factor de aprendizagem, inovação institucional e cidadania: o caso da política do ordenamento do território em Portugal. Revista Brasileira de Estados Urbanos e Regionais, 12 (1), 9-28.

Flyvbjerg, B. (2006). Five misunderstandings about case-study research. Qualitative inquiry, 12(2), 219-245.

Flyvbjerg, B. (2013) How planners deal with uncomfortable knowledge: The dubious ethics of the American Planning Association. Cities, 32, 157-163. 
Gosling, V.K. (2008). Regenerating communities: Women's experiences of urban regeneration. Urban Studies, 45(3), 607-626.

Goetz, E. G. (2011). Where have all the towers gone? The dismantling of public housing in US cities. Journal of Urban Affairs, 33(3), 267-287.

Gotham, K.F. (2003). Toward an understanding of the spatiality of urban poverty: the urban poor as spatial actors. International Journal of Urban and Regional Research, 27(3), 723-737.

Guerra, I. (2002) Fundamentos e Processos de Uma Sociologia de Acção - O Planeamento em Ciências Sociais. Lisboa: Principia.

Hambleton, R. \& Thomas, H. (1995). Urban Policy Evaluation - the contours of the debate. In: Hambleton R and Thomas H (Ed.) Urban Policy Evaluation - Challenge and Change. London: Paul Chapman Publishing.

Hancock, L. \& Mooney, G. (2013). "Welfare Ghettos" and the "Broken Society": Territorial Stigmatization in the Contemporary UK. Housing, Theory and Society, 30(1), 46-64.

Healey, P. (1997). Collaborative Planning. London: Macmillan.

Healey, P., Cars, G., Madanipour, A. \& Magalhães, C. (2002) Transforming governance, institutionalist analysis and institutional capacity. In: Cars, G., Healey, P., Madanipour, A. \& Magalhães, C. (Ed.) Urban Governance, Institutional Capacity and Social Milieux (pp.6-28) London: Ashgate Publishing.

Jensen, S.Q. \& Christensen, A. (2012) Territorial stigmatization and local belonging: A study of the Danish neighbourhood Aalborg East. City, 16(1-2), 74-92.

Kearns, A. \& Parkinson, M. (2001) The Significance of Neighbourhood. Urban Studies, 38(12), 2103-2110.

Kearns, A. \& Mason, P. (2015). Regeneration, relocation and health behaviours in deprived communities. Health \& Place, 32, 43-58. 
Klecun, E. \& Cornford, T. (2005). A critical approach to evaluation. European Journal of Information Systems, 14, 229-243.

Lawless, P. (2012) Can area-based regeneration programmes ever work? Evidence from England's New Deal for Communities Programme. Policy Studies, 33(4), 313-328.

Lobao, L., Hooks, G. \& Tickamyer, A. (2007) The Sociology of Spatial Inequality. Albany: State University of New York Press.

Michalski, A. (2012). Social Welfare and Levels of Democratic Government in the EU, Journal of European Integration, 34(4), 397-418.

Murie, A. \& Musterd, S. (2004) Social Exclusion and Opportunity Strctures in European Cities and Neighbourhoods. Urban Studies, 41(8), 1441-1459.

Parés, M., Bonet-Martí, J. \& Martí-Costa, M. (2011) Does participation really matter in urban regeneration policies? Exploring governance networks in Catalonia (Spain) Urban Affairs Review. DOI: 1078087411423352.

Power, S., Rees, G. \& Taylor, C. (2005) New Labour and educational disadvantage: the limits of area-based initiatives. London review of education, 3(2), 101-116.

Pugalis, L. (2013). Hitting the target but missing the point: the case of area-based regeneration. Community Development, 44(5), 617-634.

Rae, A. (2011). Learning from the Past? A Review of Approaches to Spatial Targeting in Urban Policy. Planning Theory and Practice, 12(3), 331-348.

Rhodes, J., Tyler, P. \& Brennan, A. (2005) Assessing the effect of Area Based Initiatives on Local Area Outcomes: Some thoughts based on the National Evaluation of the Single Regeneration Budget in England. Urban Studies, 42(11), 1919-1946.

Sanderson, I. (2002) Evaluation, policy learning and evidence-based policy making. Public administration, 80(1), 1-22.

Soja, E. (2009). The city and spatial justice. Justice Spatiale/Spatial Justice, 1. 
Spicer, N. \& Smith, P. (2008). Evaluating Complex, Area-Based Initiatives in a Context of Change The Experience of the Children's Fund Initiative. Evaluation, 14(1), 75-90.

Spicker, P (2007). The idea of Poverty. London: Policy Press.

Stame, N (2004). Theory-Based Evaluation and Types of Complexity. Evaluation, 10(1), 58-76.

Swianiewicz, P., Atkinson, R \& Baucz, A (2011). Background Report on the urban dimension of the Cohesion Policy post 2013. Warsaw: Polish EU Presidency.

Tyler P., Warnock C., Provins A. and Lanz B. (2013). Valuing the Benefits of Urban Regeneration. Urban Studies 50(1): 169-190.

Turok, I, Kearns, A and Goodlad, R (1999) Social exclusion: In what sense a planning problem. Town Planning Review, 70(3), 363.

Uitermark, J. (2013). Integration and Control: The Governing of Urban Marginality in Western Europe. International Journal of Urban and Regional Research, 38(4), 1418-1436.

Wacquant, L. (2007). Territorial stigmatization in the age of advanced marginality. Thesis Eleven, 91(1), 66-77.

Wacquant, L. (2014). Marginality, ethnicity and penality in the neo-liberal city: an analytic cartography. Ethnic and Racial Studies, 37(10), 1687-1711.

Wacquant, L., Slater, T. and Pereira, V.B. (2014) Territorial stigmatization in action. Environment and Planning A, 46(6), 1270-1280.

Wassenberg, F. (2011). Demolition in the Bijlmermeer: lessons from transforming a large housing estate. Building Research \& Information, 39(4), 363-379.

Yin, R. (2014). Case Study Research: design and methods. United States of America: Sage Publications. 